\title{
Diggers, gliders and runners: The squirrels from the Ribesalbes-Alcora Basin (East of Spain)
}

\author{
Vicente D. Crespo, Ana Fagoaga, Francisco J. Ruiz-Sánchez \& Plini Montoya
}

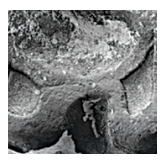

The Campisano Ravine in the Ribesalbes-Alcora Basin (Spain, early Miocene, biozone C, MN 4) yielded a relatively diverse assemblage of squirrels, composed by the ground squirrels Heteroxerus rubricati, Atlantoxerus blacki and Aragoxerus sp. the marmotines Palaeosciurus cf. sutteri, Spermophilinus sp., Marmotini indet. and the flying squirrel Aliveria cf. luteyni. Heteroxerus rubricati, Atlantoxerus blacki and Spermophilinus are typical early Miocene species from the Iberian Peninsula, and in this work we increase the knowledge of the variability of them. In MN4, the genus Aragoxerus is reported for the first time in the Iberian Peninsula, and, apart from France, it is its only record in Europe. We report here the first record of the species Palaeosciurus cf. sutteri in the Iberian Peninsula, and one of the oldest in Europe. The occurrence of Aliveria cf. luteyni marks the first record of the genus Aliveria in Western Europe. Additionally, the palaeoecological significance of this assemblage is discussed. - Key words: Sciuridae, Miocene, Aragonian, Iberian Peninsula, paleoecology, biostratigraphy.

Crespo, V.D., Fagoaga, A., Ruiz-SÁnchez, F.J. \& Montoya, P. 2021. Diggers, gliders and runners: The squirrels from the Ribesalbes-Alcora Basin (East of Spain). Bulletin of Geosciences 96(1), 83-97 (3 figures, 2 tables). Czech Geological Survey, Prague. ISSN 1214-1119. Manuscript received June 7, 2020; accepted in revised form November 16, 2020; published online December 6, 2020; issued January 10, 2021.

Vicente D. Crespo, Consejo Nacional de Investigaciones Cientificas y Técnicas, División de Paleontología de Vertebrados, Museo de La Plata (UNLP), Paseo del Bosque s/n, B1900FWA La Plata, Argentina \& Museo Paleontológico de Alpuente, Av. San Blas 17, Alpuente, 46178 Valencia, Spain \& Museu Valencia d'Història Natural, L'Hort de Feliu, P.O. Box 8460, Alginet, 46018 Valencia, Spain; vidacres@gmail.com • Ana Fagoaga, Museu Valencia d'Història Natural, L'Hort de Feliu, P.O. Box 8460, Alginet, 46018 Valencia, Spain \& Departament de Geologia, Universitat de València, Dr. Moliner 50, 46100, Burjassot, Valencia, Spain • Francisco J. Ruiz-Sánchez, Museu Valencia d'Història Natural, L'Hort de Feliu, P.O. Box 8460, Alginet, 46018 Valencia, Spain \& Departament de Geologia, Universitat de València, Dr. Moliner 50, 46100, Burjassot, Valencia, Spain \& Universidad Estatal Península de Santa Elena, 7047, Santa Elena, Ecuador • Plini Montoya, Departament de Geologia, Universitat de València, Dr. Moliner 50, 46100, Burjassot, Valencia, Spain

The family Sciuridae currently comprises more than 273 species and 50 genera, distributed in all continents except Australia and Antarctica. This group, together with the mountain beavers (Aplodontiidae) constitute the Suborder Sciurida in the order Rodentia (McKenna \& Bell 1997, Churakov et al. 2010).

In the Miocene the sciurids experienced a big ecomorphologic diversification (with terrestrial, arboreal and gliding forms) as well as a substantial increase in diversity, with up to six species coexisting in some sites. In the PlioPleistocene transition, this family underwent a crisis, with less genera surviving in Europe than before, reflecting the deterioration of the climate (de Bruijn 1999). In the Iberian Peninsula, the dominant ecomorphological type during the early Miocene are the ground squirrels, with a combined representation of the genera Heteroxerus and Atlantoxerus at many sites, accompanied to a lesser degree by Aragoxerus, Spermophilinus and Palaeosciurus (Cuenca-Bescós 1988, Aldana-Carrasco 1992, Ruiz-Sánchez et al. 2003, Van der Meulen et al. 2012, Casanovas-Vilar et al. 2016,
García-Paredes et al. 2016, Hernández-Ballarín \& PeláezCampomanes 2018).

The fossil flying squirrels along the early Miocene of the Iberian Peninsula are restricted to a few records, assigned to different genera (Casanovas-Vilar et al. 2015). The oldest record corresponds to Blackia miocaenica Mein, 1970 from the Ramblian of Rubielos de Mora 2 (MN3, Rubielos de Mora Basin; de Bruijn \& Moltzer 1974) and Buñol (MN4, Magro Basin; Robles et al. 1991); in the latter locality it occurs together with another flying squirrel, Miopetaurista diescalidus Daams, 1977. Finally, the genus Albanensia is recorded in the sites of Barranco de Candel (MN4, Margo Basin; Adrover et al. 1987) and Montalvos 2, as Albanensia cf. sansaniensis (Lartet, 1851) in this site (Hordijk et al. 2015).

This paper continues a serie of works that deal with small mammals from the Ribesalbes-Alcora Basin. Among the published results, some worth mentioning are: the southernmost documented record of the herpetotheriid Amphiperatherium frequens (von Meyer, 1846) (Crespo 
et al. 2020, Furió et al. 2012); the new species Plesiodimylus ilercavonicus Crespo, Furió, Ruiz-Sánchez \& Montoya, 2018 (Crespo et al. 2018); the abundant remains of talpids (Crespo et al. 2019b); the diversity of soricids (Crespo et al. 2019c) and erinaceids (Crespo et al. 2020). The rest of groups will be published soon.

\section{Geographic and geologic setting}

The materials studied here have been recovered near the village of Araia d'Alcora (Ribesalbes-Alcora Basin, eastern Iberian Peninsula; Fig. 1; Agustí et al. 1988, Crespo et al. 2019a). The synthetic stratigraphic column (Fig. 1) is composed of seven sections, which have been named, from oldest to youngest (with some overlap) as: Mas dels Coixos, Mas de Torner, Araia Cantera Sud, Barranc de Campisano, Foieta la Sarra, Mas d'Antolino B and Corral de Brisca. The sediment beds mainly consist of grey and yellow mudstones, limestones and sandstones, about $100 \mathrm{~m}$ thick (Crespo et al. 2019a), and are included in the "Unit Three" of the Ribesalbes-Alcora Basin sensu Anadón (1983).

The sites with mammalian remains from the RibesalbesAlcora Basin were first reported by Agustí et al. (1988). Until now, up to 45 sites have been described from the seven sections detailed in Crespo et al. (2019a). The studied sections represent a stratigraphic range corresponding to the local biozone $\mathrm{C}$ from the Calatayud-Daroca Basin (MN4, lower Aragonian, early Miocene), in the chronologic interval 16.5-16 Ma according to Van der Meulen et al. (2012) (Crespo et al. 2019a).

\section{Material and methods}

The photographic images of the specimens were taken with a Scanning Electron Microscope HITACHI 4800 at the Servei Central de Suport a la Investigació Experimental (SCSIE) and the optical photographic image was taken with a Leica DMS1000 from the Department of Botany and Geology, both in the University of València Estudi General (UVEG). The fossil material is stored at the Museu de la Universitat de València d'Història Natural (MUVHN), Burjassot, Spain.

We have used the nomenclature and the measuring methods of Cuenca-Bescós (1988) for the sciurids. Measurements are given in millimetres and were taken using a Leica MZ75 binocular microscope, by means of displacement of a mechanical stage, connected to a Sony Magnescale measuring equipment. Lower teeth are designated with lower-case letters (lower incisor - $\mathrm{i}$; lower deciduous - dp4; lower premolar - p4; lower molars - $\mathrm{m} 1$, $\mathrm{m} 2$ and $\mathrm{m} 3$ ) and upper teeth are written in upper case letters (upper incisor - I; upper deciduous - DP4; upper premolar-
P4; upper molars - M1, M2 and M3). Throughout the text, the names of the sections often appear abbreviated as follows: MCX - Mas dels Coixos; MTR - Mas de Torner; BC - Barranc de Campisano; FS - Foieta la Sarra; MAB Mas d'Antolino B; CBR - Corral de Brisca.

\section{Results}

Class Mammalia Linnaeus, 1758

Order Rodentia Bowdich, 1821

Suborder Sciuromorpha Brandt, 1855

Infraorder Sciurida Carus, 1868

Family Sciuridae Fischer, 1817

Subfamily Xerinae Osborn, 1910

Tribe Xerini Murray, 1866

\section{Genus Heteroxerus Stehlin \& Schaub, 1951}

\section{Heteroxerus rubricati Crusafont, Villalta \& Truyols, 1955}

Figure 2

Material. - MCX3 - 1 m1, 1 M1; MTR2 - 1 m1; MTR3 $1 \mathrm{~m} 1$; BC1 - 1 dp4, 1p4, 1 m1, 2 m2, 1 DP4; FS1 - 2 m1, 1 DP4, 1 M1; MAB3 - 1 dp4, 2 p4, 1 m1, 2 m2, 3 M1, 4 M2, 2 M1/M2; MAB5 - 1 M1; MAB8 - 1 m3; MAB11 1 DP4; CBR0B - 1 m1, 1 DP4, 1 M1/M2; CBR0C - 1 DP4.

Measurements. - See Tab. 1.

Description. $-\mathrm{dp} 4$ (Fig. 2A, B): The outline is subtriangular. The metaconid and the protoconid are the largest cusps and they are located next to each other. The anteroconulid is small and the metalophid is not present in the specimen from $\mathrm{BC} 1$, while in the tooth from $\mathrm{MAB} 3$ is small. The metaconid and the entoconid are connected by the mesolophid. The protoconid and the mesoconid are linked by a crestid. The entolophid is complete and connects the hypoconid and the entoconid. In the material from $\mathrm{BC} 1$ the entolophid shows a narrowing near the entoconid. The hypoconulid is well developed and incomplete. The roots are divergent.

p4 (Fig. 2C, D): The outline is subtriangular, shorter than the dp4. The metaconid and the protoconid are the largest cusps. In MAB3 the anteroconulid is spur-shaped, while in the other specimens it is reduced. The mesolophid could be a crestid that connected the metaconid and the entoconid (in one tooth) or a spur of the metaconid (in the other tooth). A crestid connects the protoconid and the mesoconid. In MAB3 the entolophid is complete and connects the hypoconulid and the entoconid (in one tooth) or it is incomplete (in the other tooth); in the $\mathrm{BC} 1$ specimen it is curved and it does not reach the posterolophid, and the 

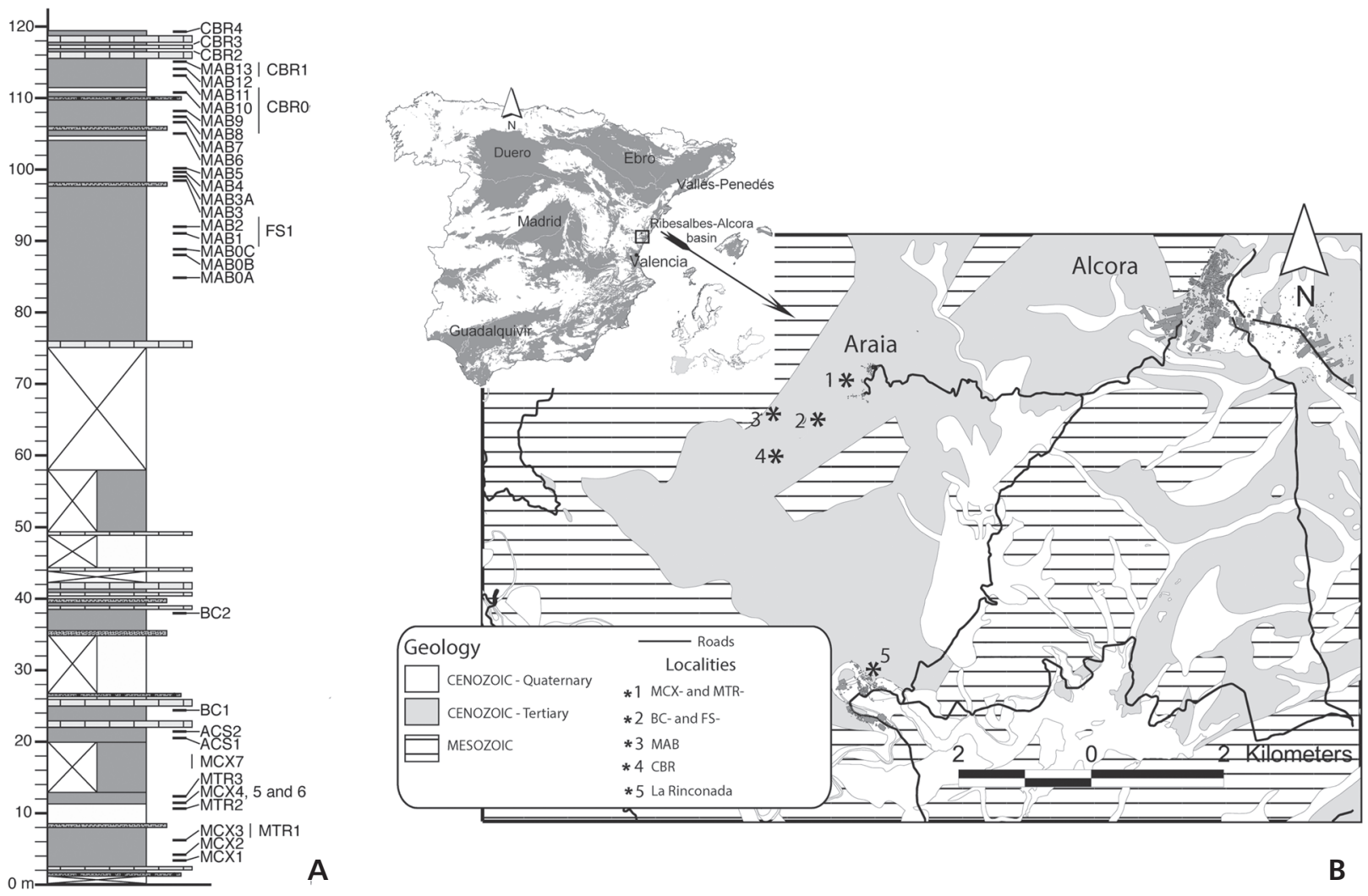

Figure 1. A - synthetic column of the Campisano ravine with the situation of the studied sites. $\bullet$ B - Spanish Cenozoic basins, with location of the Ribesalbes-Alcora Basin and the schematic distribution of sediments and the position of the studied fossil sites. Abbreviations: ACS - Araia Cantera Sud; BC - Barranc de Campisano; CBR - Corral de Brisca; FS - Foieta la Sarra; MAB - Mas d'Antolino B; MCX - Mas dels Coixos; MTR - Mas de Torner. La Rinconada is the classical Fossil-Lagerstätte site with remains of insects, plants and amphibians. Modified from Crespo et al. (2018, 2019a). Scale bar is $2 \mathrm{~km}$.

hypoconulid is absent. The posterolophid is incomplete, and in $\mathrm{BC} 1$ it is divided.

$\mathrm{m} 1$ (Fig. 2E-G): The outline is subrectangular. The four principal cuspids are well developed, and the metaconid is the largest one. The anteroconulid is well developed in MAB3 and MCX3; in MTR3 it is isolated, in FS1 it may be well developed (in one tooth) or not (in the other tooth), and in CBR0B it is almost isolated. In MAB3 and MCX3 the anterolophid and the anterior cingulid are short and isolated in their distal parts; in MTR3 the anterolophid is absent and the anterior cingulid is very small; in FS1 it is long and surrounds the protoconid; in CBR0B it is short and connected to the metaconid, and with a short anterior cingulid connected to the protoconid. The metalophid is curved and complete in the material from MAB3 and MCX3; in the teeth from MTR2 and FS1 it is shorter and its ending is isolated; in the tooth from MTR3 it is sigmoidal. The mesolophid in MAB3, MCX3 and FS1 is a spur of the entoconid, while in MTR2 it is absent. The mesoconid and the hypoconulid are not present in MAB3 and $\mathrm{MCX} 3$, but there is a crest that joins the hypoconid and the protoconid; in FS1 and CBR0B this crest is narrower near the hypoconid. The entolophid is complete and sigmoidal in MAB3 and MCX3, while in MTR3 it is curved and connected to a small hypoconulid; in FS1 it is complete and straight and in CBR0B it is curved. The posterolophid is not connected to the entoconid. In FS1 the hypoconulid is an enlargement of a complete posterolophid.

$\mathrm{m} 2$ (Fig. 2H-J): The outline is quadrate. The four principal cuspids are well developed, and the metaconid is the largest one. The anteroconulid is well developed. The anterolophid is long and connected to the metaconid. The anterior cingulid is short and directed downward, towards the base the crown, in MAB3, while in $\mathrm{BC} 1$ it is connected to the protoconid and the metalophid. The metalophid is short and isolated. In MAB3, the mesolophid is absent (in one tooth) or it merely consists in a small enlargement (in the other tooth). The mesoconid is a small enlargement. In MAB3, the crest that connects the protoconid and the metaconid is narrower near the hypoconid (in one tooth) or continuous (in the other tooth). The entolophid is complete and curved; it is connected to the complete posterolophid. The hypoconid is not present. One of the teeth from BC1 is larger in size (Tab. 1). 
m3 (Fig. 2K): A fragmented tooth with a rounded posterior side. The anterior cingulid is connected to the protoconid. The metalophid is short and isolated in its ending part. The mesoconid is an enlargement of the crestid that connects the protoconid with the hypoconid, and shows a narrowing near the hypoconid. The posterolophid is well developed.

DP 4 (Fig. 2L, M): The outline is subtriangular, with a protruding front end. The anteroloph is curved, with a weak contact with the protocone and isolated from the small paracone. The protoloph is short and connected to a big protocone. The protocone from $\mathrm{CBR} 0 \mathrm{C}$ and $\mathrm{BC} 1$ is closer to the centre of the tooth than in the material from the other sites. The mesostyle is weak. The metacone is weakly developed. The metaconule is larger than the metacone, and it is almost isolated, only slightly connected to the metacone and the posteroloph, which is well developed, and connected to the hypocone and the metacone. In the material from $\mathrm{CBR} 0 \mathrm{C}$ and $\mathrm{BC} 1$ the posteroloph is weaker than in the other sites and connected directly with the metaconule. The hypoconule is absent. The tooth from CBR0B is large in size.

M1 (Fig. 2N, O): The outline is quadrate, with four principal cusps. In MAB3, the anteroloph it is long and straight and in one specimen is connected to the paracone, and in the other it is not connected. The anteroconule is a small enlargement. The protoloph is straight, and downwards oriented in the middle of the tooth, and it connects the paracone with the protocone. The mesostyle is weak. The protocone and the hypocone are connected by a strong crest. In MAB3, the metaloph is strong, straight and either long (in one tooth) or short (in the other tooth). The metaconule is weak and connected to the posteroloph, except in the material from MAB5 where it is connected to the crest that runs from the protocone to the hypocone. In MAB3 the posteroloph may be, either long and strong ( 1 out of 2 specimens) or short ( 1 out of 2 ), and either connected to the metacone (1 out of 2 ) or not (1 out of 2 ).

M2 (Fig. 2P, Q): the outline is subquadrate, with four principal cusps. The anteroloph is long and straight, the anteroconule is a small enlargement that becomes narrower next to the protocone. The protoloph is straight and well developed, and it connects the paracone with the protocone. The mesostyle is either small, in one specimen, or absent, in another. The protocone and the hypocone are connected by a crest, which can be well developed (2 out of 4) or weak ( 2 out of 4$)$. The metacone is well developed. The metaloph may be weak ( 1 out 3 ) or strong ( 2 out of 3 ). The metaconule is either well developed ( 3 out of 4 ) or small (in the remaining tooth), and it is connected to the posteroloph. The last crest can be short (1 out of 4) or long (3 out of 4).

Remarks. - This ground squirrel is mentioned by Agustí et al. (1988) in the Ribesalbes-Alcora Basin, in the classic locality of Araia, but the authors did not describe the material and they considered it as a doubtful form (cf.). The genus Heteroxerus is common in the Neogene from Europe (Cuenca-Bescós 1988, de Bruijn 1999), and it constitutes the best represented squirrel in the Ribesalbes-Alcora Basin sites. The species Heteroxerus rubricati is characterized by having upper molars with four principal cusps, the metaloph is incomplete, reduced and isolated or semi-isolated from the protocone and the metaconule is well developed (Cuenca-Bescós 1988). In the lower molars, the four cuspids are well developed, there is a well-developed entoconid, a reduced metalophid, a large anteroconulid and hypoconulid, and sometimes an anterior cingulid (Cuenca-Bescós 1988). Furthermore, for $H$. rubricati, this author proposes an emended diagnosis wherein she denotes the presence of an incomplete metaloph, either with a free ending or connected to the posteroloph, a complete or absent metalophid, and a scarcely present mesostylid. These characteristics can be observed in the material from Ribesalbes-Alcora Basin, and allow us to assign it to this species. Heteroxerus rubricati differs from Heteroxerus vireti Black, 1965 by a short and low entolophid, without connection with the hypoconulid, and the absence of the anterior cingulid. Additionally, in Heteroxerus grivensis (Forsyth Major, 1893) the anterior cingulid is absent (Aldana-Carrasco 1992).

Cuenca-Bescós (1988) divided the upper molars in four groups, according to the connections of the metaconule. The material here studied belongs to the morphologies 2 (without connection to the posteroloph) and 3 (with one connection to the posteroloph) for the M1 and M2; both morphologies are the most common in the CalatayudMontalbán Basin. Regarding to the lower teeth, this author divided the morphologies in three groups (5 to 7) depending on the relative development of the anterior cingulid. In the Ribesalbes-Alcora Basin, the material belongs to morphologic group 5 (anterolophid absent in the p4 and very short in the molars). However, in $\mathrm{BC} 1$ there is a molar that belongs to group 7 (very long anterolophid). Overall, the morphological characters present in the material from the Ribesalbes-Alcora Basin are within the variability of the teeth from the Calatayud-Montalbán Basin. As for the morphometric variability, generally, the specimens are in the lower part of the variation range present in the Calatayud-Montalbán Basin, except for the material from $\mathrm{BC} 1$, and the upper molars from MAB3 that are rather medium-large in size.

Occurrence. - Mas dels Coixos 3 (MCX3), Mas de Torner 2 and 3 (MTR2 and MTR3), Barranc de Campisano 1 (BC1), Foieta la Sarra 1 (FS1), Mas d'Antolino B 3, 5, 8 and 11 (MAB3, MAB5, MAB8 and MAB11); Corral de Brisca 0B and $0 \mathrm{C}$ (CBR0B and $\mathrm{CBR} 0 \mathrm{C})$. 


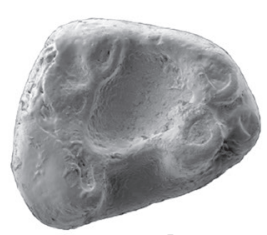

A

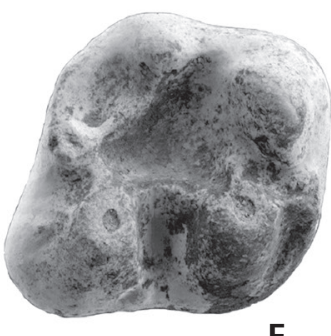

$\mathbf{F}$

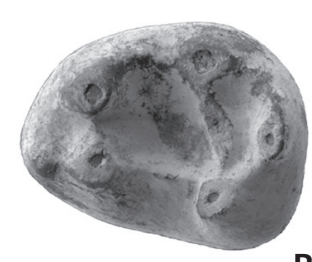

B

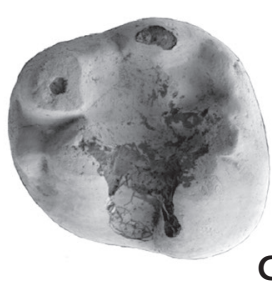

C

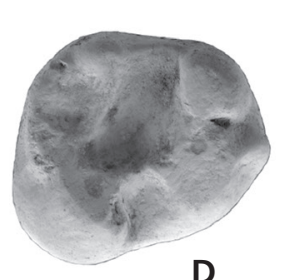

D

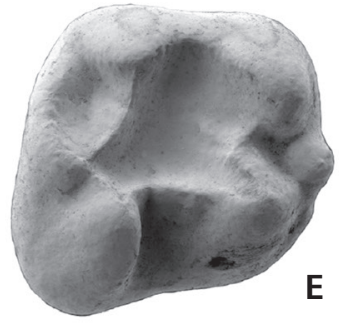

E
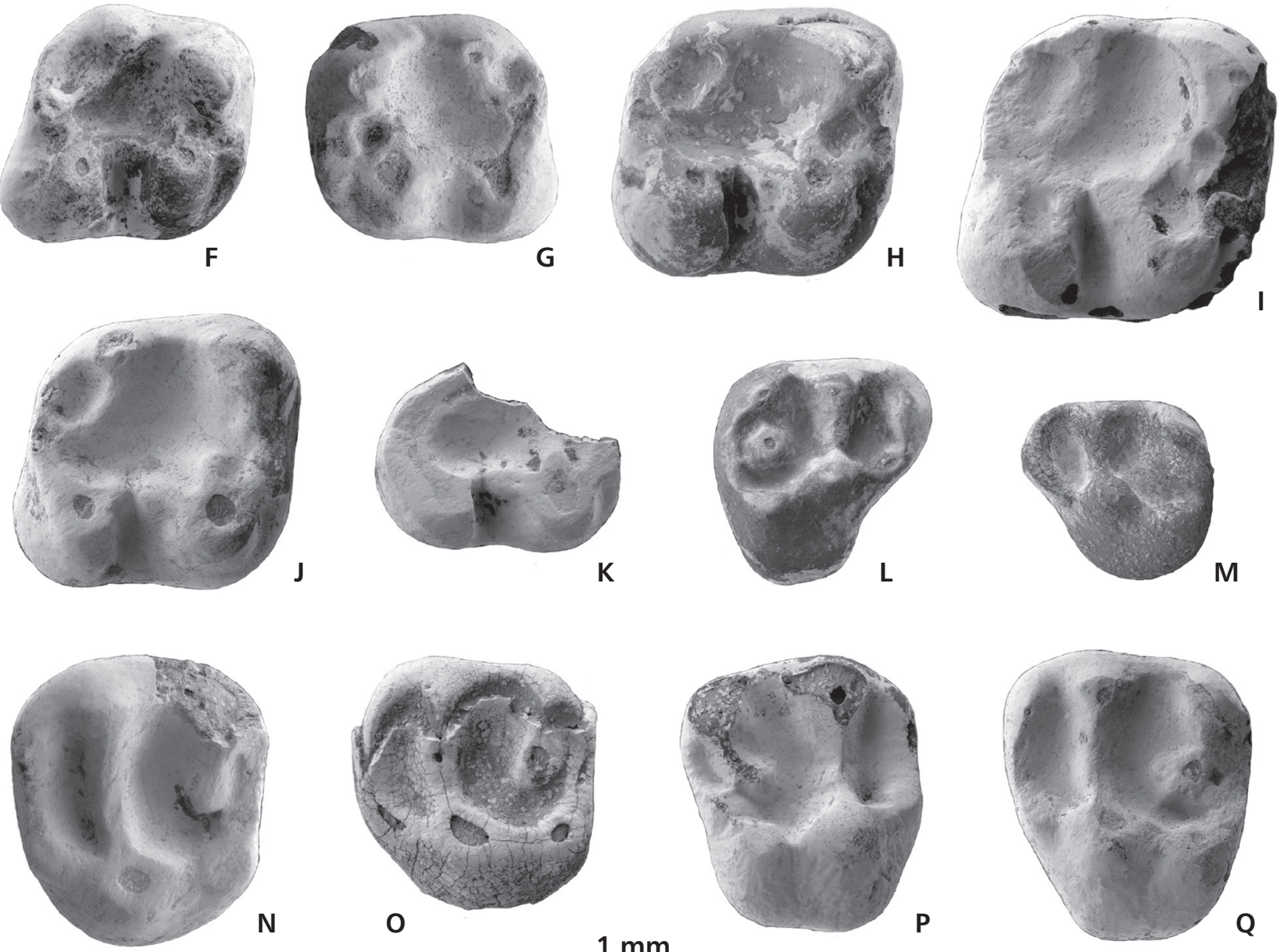

N
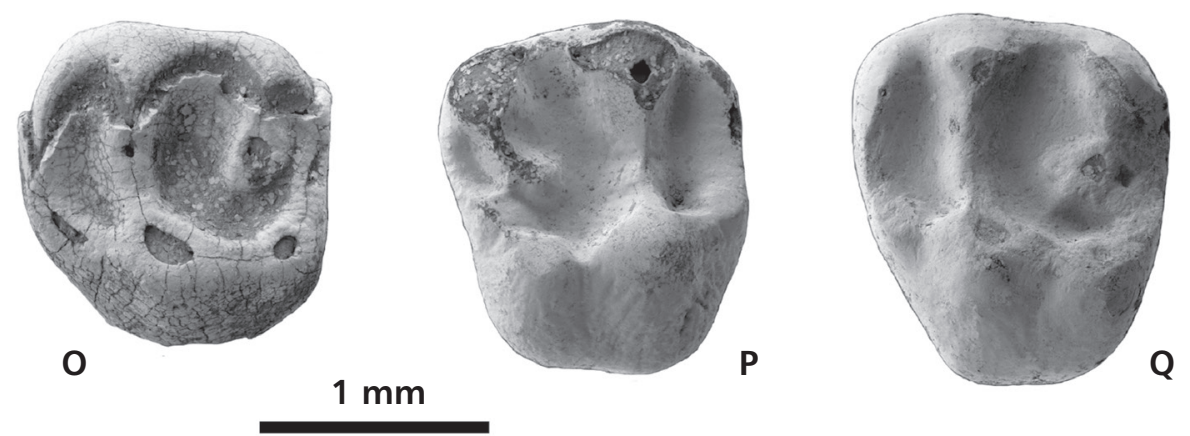

Figure 2. Teeth of Heteroxerus rubricati Crusafont et al., 1955 from the Ribesalbes-Alcora Basin. A - right dp4 (BC1-18); B - left dp4 (MAB3-674); C - left p4 (MAB3-672); D - right p4 (MAB3-675); E - right m1 (MTR3-2); F - right m1 (FS1-64); G - left m1 (MAB3-670); H - right m2 (BC1-150); I - right $\mathrm{m} 2$ (BC1-151); J - right m2 (MAB3-671); K - right m3 (MAB8-6); L - right DP4 (MAB11-13); M - left DP4 (CBR0C-1); N - right M1 (MAB3-666); O - right M1 (MAB5-137); P - left M2 (MAB3-668); Q - right M2 (MAB3-678). Scale bar is $1 \mathrm{~mm}$.

\section{Genus Atlantoxerus Forsyth Major, 1893}

\section{Atlantoxerus blacki de Bruijn, 1967}

Figure $3 \mathrm{~A}-\mathrm{F}$

Material.-MCX1: 1 M1; MCX3: 1 M1/M2; MAB3: 1 d4, $1 \mathrm{p} 4,1$ D4; MAB5: 1 m1, 1 M1, 1 M3.

Measurements. - See Tab. 1.
Description.-dp4 (Fig. 3 A): The outline is subtriangular. The anteroconulid is small and isolated. The metaconid and the protoconid are well developed, and connected by a short metalophid. The mesolophid and the mesoconid are crest-shaped. The entolophid is well developed and connected to the entoconid. The posterolophid is long and complete.

p4 (Fig. 3B): The outline is subtriangular. The anteroconulid is absent. The metaconid and the protoconid are 
well developed and connected by a short metalophid. The mesolophid is absent. The mesoconid is crest-shaped. The entoconid is poorly developed, and gives rise to a curved entolophid that is connected to the hypoconulid. The posterolophid is short and not connected to the entoconid.

$\mathrm{m} 1$ (Fig. 3C): The outline is subquadrate. The anteroconulid and the anterolophid are small, the latter is connected to the metaconid. The anterior cingulid is shorter than the anterolophid and it is connected to the protoconid. The metalophid is weak and almost divided in two. The mesostylid is absent and the mesoconid has a crest shape. The entoconid is the smallest of the four principal cusps. The entolophid is curved and connected to a well-developed hypoconid. The posterolophid is short and complete.

DP 4: The tooth is broken and rounded with a truncated pyramid shape outline. The protocone is the best developed cusp. The protoloph is straight and connected to a low paracone. The metacone is small and connected to a welldeveloped hypoconule. The posteroloph is long.

M1 (Fig. 3D, E): The tooth from MAB5 is broken, it is large and with a rounded outline. The protocone is the highest cusp, with the hypocone lower than the protocone. The protoloph is straight. In the tooth from MCX1 the anteroloph is straight, long and open, the anteroconule is developed and the mesostyle is small. The paracone and the metacone are reduced and the protoloph is long and straight.

M3 (Fig. 3F): A large broken tooth with a rounded outline. The anteroloph is curved, with a small parastyle that ends near the paracone. The anteroconule is well developed. The protocone is the largest cusp. The paracone is small; it is connected by a straight protoloph to a small protoconule, and becomes narrower next to the protocone. The metaloph is long, poorly developed and divided in two. Both the metaconule and the hypoconule are well developed and connected to each other. The hypocone is poorly developed.

Remarks. - Atlantoxerus is a genus of ground squirrels that includes the extant Barbary ground squirrel [Atlantoxerus getulus (Linnaeus, 1758)]. It had not been described previously in the Ribesalbes-Alcora Basin. It can be easily distinguished from the genus Heteroxerus, in spite of their similar morphology, by its large size and its smaller anterolophid. (Cuenca-Bescós 1988, Peláez-Campomanes 2001). Furthermore, Atlantoxerus has more robust and rounded cusps, with well-developed anteroconules and hypoconules. The material studied here shows a complete anteroloph and a low metaloph connected to the posteroloph; this character is present in the material from some sites in the Calatayud-Montalbán Basin (CuencaBescós 1988).

Peláez-Campomanes (2001) puts in synonymy Atlantoxerus idubedensis Cuenca-Bescós, 1988 with $A$. blacki. Following the emended diagnosis proposed by this author for $A$. blacki, the material studied here presents a $\mathrm{d} 4$ with an anteroconulid and entolophid connected to the hypoconid; the $\mathrm{p} 4$ without anteroconulid; in the $\mathrm{m} 1$ the entolophid is connected to the hypoconid, and the metalophid is almost disconnected; the upper molars have a differentiated anteroconule and hypoconule; the metaconule is connected to the posteroloph and there is a small protoconule. These characters are described as diagnostic for this species and allow its distinction from the other early Miocene species of this genus. In addition, $A$. blacki differs from Atlantoxerus martini Aguilar, 2002 in its better developed anterior cingulid, and from both A. martini and Atlantoxerus vireti (Black, 1965) in its larger size (Aguilar 2002).

The biometric analysis shows that the $\mathrm{d} 4$ is in the lower limit size range of $A$. blacki within the CalatayudMontalbán Basin, whereas the $\mathrm{p} 4$ is smaller and the $\mathrm{m} 1$ and M3 are located in the medium area, but narrower. This is in agreement with the great biometric variability described for this species by Peláez-Campomanes (2001).

Occurrence. - Mas dels Coixos 1 and 3 (MCX1 and MCX3), Mas d'Antolino B 3 and 5 (MAB3 and MAB5).

\section{Genus Aragoxerus Cuenca-Bescós, 1988}

\section{Aragoxerus sp. \\ Figure $3 \mathrm{G}, \mathrm{H}$ \\ Material. - CBR0B - $1 \mathrm{p} 4$; CBR1 - $1 \mathrm{~m} 1 / \mathrm{m} 2$.}

Measurements. - See Tab. 1.

Description. $-\mathrm{p} 4$ (Fig. 3G): The surface is rounded with a subeliptical outline. Only the four principal cusps are present, without conules. The senid is poorly developed.

$\mathrm{m} 1 / \mathrm{m} 2$ (Fig. $3 \mathrm{H})$ : A broken tooth with a very small size. The anteroconulid is well developed and the metalophid is connected to it. The mesoconid has a crestlike shape. The senid is absent.

Remarks. - Among the fossil Sciuridae recovered in the Ribesalbes-Alcora Basin, the material ascribed to this ground squirrel shows the smallest size. Despite the fact that this material is fragmentary, some typical characteristics of this genus described by Cuenca-Bescós (1988) can be observed, such as the small size of the teeth, the absence of the senid and the labial cingulid and the small or absent anteroconulid. The material here described differs from Aragoxerus ignis (Cuenca-Bescós, 1986) in its better-developed cuspids (Cuenca-Bescós 1988) and from both A. ignis and Aragoxerus nov. sp. from Baixas and Saint Catherine (France) in its smaller size (Aguilar 2002). Although, Aragoxerus is considered a nomen dubium by de Bruijn (1999), or a synonym of Heteroxerus by Krystufek et al. 

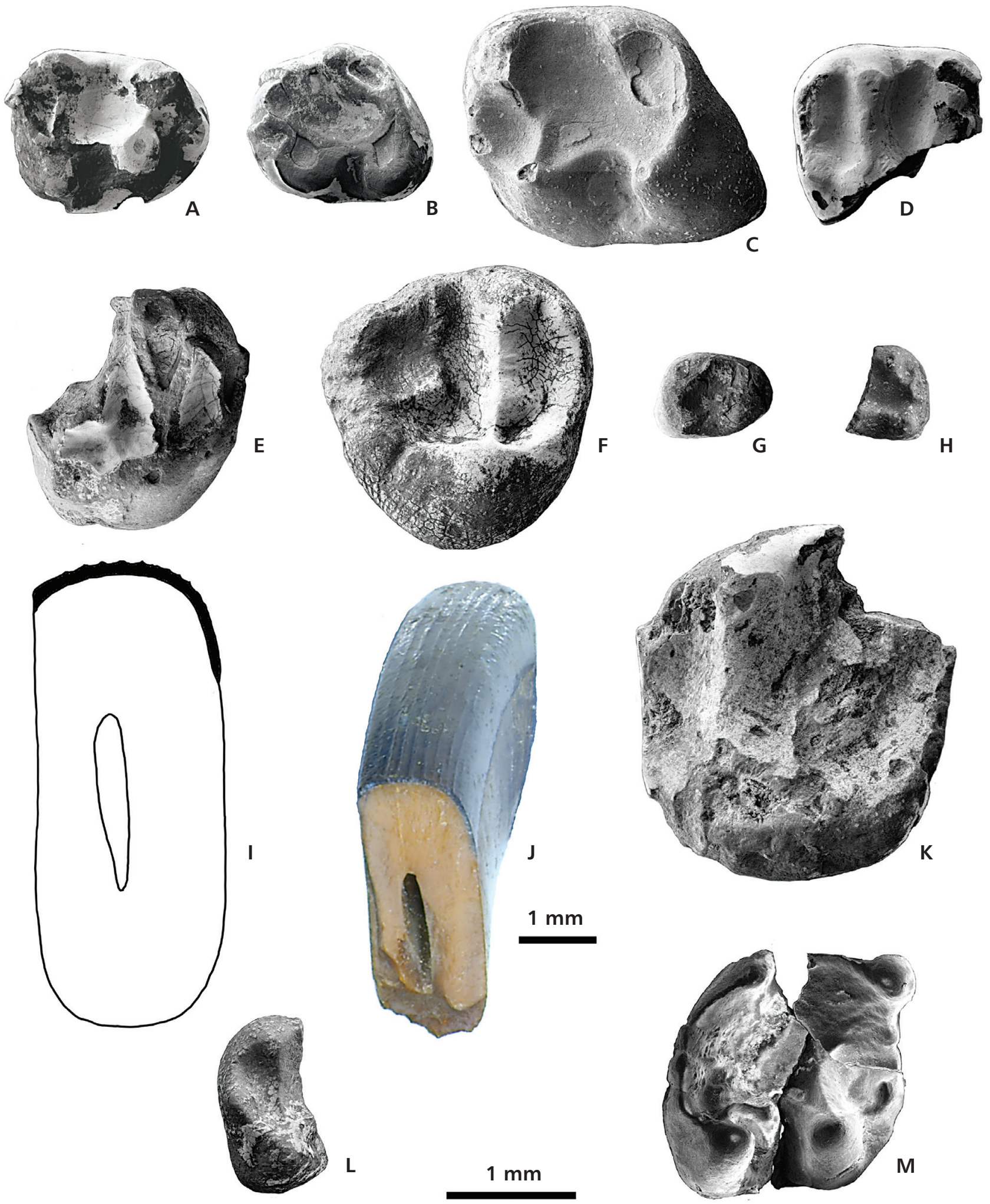

$\mathbf{L}$

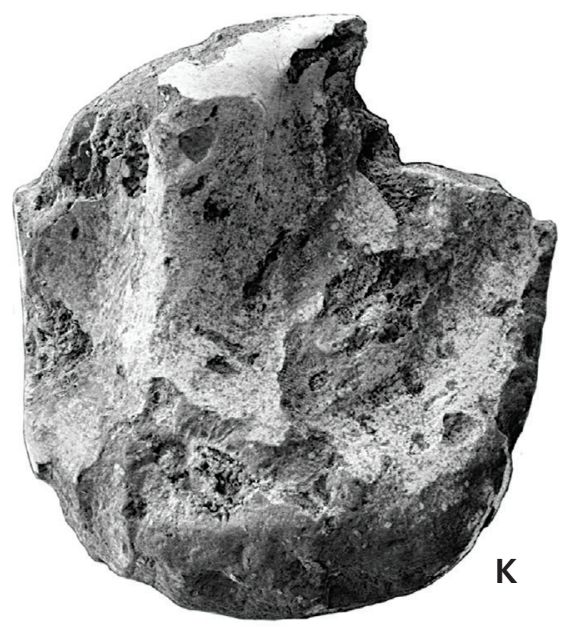

Figure 3. Teeth of the family Sciuridae (except Heteroxerus rubricati) from the Ribesalbes-Alcora Basin. • A-F - Atlantoxerus blacki de Bruijn, 1967; A - right dp4 (MAB3-673); B - left p4 (MAB3-669); C - left m1 (MAB5-717); D - right M1 (MCX1-5); E - left M1 (MAB5-44); F - left M3 (MAB5-716). - G, H - Aragoxerus sp.; G - right p4 (CBR0B-39); H - right m1/m2 (CBR1-44).・ I, J - Marmotini indet.; I - (MAB3-696). • $\mathrm{K}-$ Palaeosciurus cf. sutteri Ziegler \& Falhbusch, 1986, right M1/2 (MAB3-665). $\bullet \mathrm{L}-$ Spermophilinus $\mathrm{sp}$. , left m1/m2 (MAB5-718). $・ \mathrm{M}-$ Aliveria cf. luteyni de Bruijn et al., 1980; right $\mathrm{m} 1 / \mathrm{m} 2$ (CBR0B-53). Scale bar is $1 \mathrm{~mm}$. 
(2016). The latter authors do not justify their synonymy and the remains described here are morphologically and biometrically distinct from the Heteroxerus rubricati of the sites from Ribesalbes-Alcora Basin. Therefore, and due to the scarcity of material, we prefer not to assign it to any particular species.

Occurrence. - Corral de Brisca 0B and 1 (CBR0B and CBR1).

Tribe Marmotini Pocock, 1923

\section{Marmotini indet.}

Figure 3I, J

Material. - MAB3 - 1 I.

Measurements. - See Tab. 1.

Description. - I (Fig. 3 I, J): A fragment of a large upper incisor, with a subrectangular transversal section and an oval central channel. The enamel has ten central longitudinal crests.

Remarks. - A large upper incisor has been found in MAB3. By its strong labiolingual compression, flattened anterior wall with finely striated enamel (Fig. 3J) restricted to anterior and, partially, labial walls but devoid the lingual wall belongs to a marmotine ground squirrel. Although, the cross-section of the incisor is similar to the genus Spermophilinus-like or Tamias-like appearance, shared by a number of primitive marmotins (Sinitsa 2018), we discard Spermophilinus by its size, because it is larger than the remains of this genus found in this basin.

Occurrence. - Mas d'Antolino B 3 (MAB3).

\section{Genus Palaeosciurus Pomel, 1853}

Palaeosciurus cf. sutteri Ziegler \& Falhbusch, 1986 Figure 3K

Material. - MAB3 - 1 M1/2.

Measurements. - See Tab. 1.

Description. - M1/2 (Fig. 3K): A broken tooth with a rounded outline. The anteroloph is well developed. The only lingual cusp is the protocone, which is also well developed. The protoloph is lower than the metaloph and both form an acute V-shaped figure with the protocone. The metacone is well developed. The mesostyle is present and the metaconule is slightly developed. The posteroloph is well developed and straight.
Remarks. - The only marmotine tooth recovered differs from the others ground squirrels in the Ribesalbes-Alcora Basin in its larger size. It is characterized by a metaloph and a protoloph that converge to the protocone, an anteroloph and protoloph forming a U-shaped figure, and the presence of a mesostyle. This morphology is, after Cuenca-Bescós (1988), characteristic of the genus Freudenthalia nomen dubium [synonymized to Palaeosciurus by de Bruijn (1999)], Palaeosciurus according to Hugueney \& Bulot (2011) and Tamias after Bosma et al. (2013), but the latter lacks the mesostyle. Hugueney \& Bulot (2011) note that the morphological differences between Palaeosciurus feignouxi Pomel, 1853 and Palaeosciurus fissurae (Dehm, 1950) consist in the smaller size of $P$. feignouxi, which shows the metaloph and the protoloph arranged in $\mathrm{V}$, while $P$. fissurae is larger and with both crests parallel. Just like $P$. feignouxi, the species $P$. sutteri shows the metaloph and the protoloph forming a V. This is also the case in MAB3, but in our specimen the metaconule is better developed than in P. sutteri (Ziegler \& Fahlbusch, 1986). In this way, the morphology allows us to assign the tooth from MAB3 either to $P$. feignouxi or to $P$. sutteri.

The morphometric measures show that the tooth from MAB3 is larger than in $P$. feignouxi and $P$. aff. fissurae from Estrepouy (France); additionally, it is slightly larger than in P. sutteri but similar in size to $P$. cf. fissurae from Serre de Vèrges (France) (Ziegler \& Fahlbusch 1986, CuencaBescós 1988, Aguilar 2002, Hugueney \& Bulot 2011).

Based on morphological and metric similarities, this specimen has been determined as Palaeosciurus cf. sutteri.

Occurrence. - Mas d'Antolino B 3 (MAB3).

Subtribe Spermophilina Moore, 1959

\section{Genus Spermophilinus de Bruijn \& Mein, 1968}

\section{Spermophilinus sp.}

Figure 3L

Material. - MAB5 - $1 \mathrm{~m} 1 / 2$.

Measurements. - See Tab. 1.

Description. $-\mathrm{m} 1 / \mathrm{m} 2$ (Fig. 3L): Anterior fragment of tooth. The anteroconulid is as high as the protoconid. The anterior cingulid is connected to the protoconid and the anterolophid is less developed, although it is connected to the metaconid, which is lower than the protoconid. The metalophid is weak, but complete, and it is connected to the crestid that connects the protoconid with the hypoconid. The central valley is low and it has a well-developed senid. 
Table 1. Measurements of the teeth of squirrels from the RibesalbesAlcora Basin. L - length; W - width.

\begin{tabular}{|c|c|c|c|c|c|c|}
\hline Element & Site & Measurement & $\mathrm{n}$ & Min. & Med. & Max. \\
\hline \multicolumn{7}{|c|}{ Heteroxerus rubricati } \\
\hline \multirow[t]{4}{*}{$\mathrm{d} 4$} & $\mathrm{BC} 1$ & $\mathrm{~L}$ & 1 & & 1.25 & \\
\hline & & W & 1 & & 1.32 & \\
\hline & MAB3 & $\mathrm{L}$ & 1 & & 1.32 & \\
\hline & & W & 1 & & 1.03 & \\
\hline \multirow[t]{2}{*}{ p4 } & MAB3 & $\mathrm{L}$ & 2 & 1.15 & 1.16 & 1.16 \\
\hline & & $\mathrm{W}$ & 2 & 1.04 & 1.10 & 1.15 \\
\hline \multirow[t]{8}{*}{$\mathrm{m} 1$} & MTR3 & $\mathrm{L}$ & 1 & & 1.41 & \\
\hline & & W & 1 & & 1.42 & \\
\hline & $\mathrm{BC} 1$ & $\mathrm{~L}$ & 1 & & 1.68 & \\
\hline & & W & 1 & & 1.59 & \\
\hline & FS1 & $\mathrm{L}$ & 2 & 1.44 & 1.44 & 1.44 \\
\hline & & W & 1 & 1.29 & 1.35 & 1.41 \\
\hline & MAB3 & $\mathrm{L}$ & 1 & & 1.54 & \\
\hline & & W & 1 & & 1.34 & \\
\hline \multirow[t]{4}{*}{$\mathrm{m} 2$} & $\mathrm{BC} 1$ & $\mathrm{~L}$ & 2 & 1.68 & 1.75 & 1.81 \\
\hline & & W & 2 & 1.59 & 1.73 & 1.86 \\
\hline & MAB3 & $\mathrm{L}$ & 2 & 1.57 & 1.59 & 1.61 \\
\hline & & W & 2 & 1.49 & 1.58 & 1.67 \\
\hline $\mathrm{m} 3$ & MAB8 & $\mathrm{L}$ & 1 & & 1.51 & \\
\hline \multirow[t]{7}{*}{$\mathrm{D} 4$} & $\mathrm{BC} 1$ & $\mathrm{~L}$ & 1 & & 1.25 & \\
\hline & & W & 1 & & 1.21 & \\
\hline & FS1 & $\mathrm{W}$ & 1 & & 1.33 & \\
\hline & MAB11 & $\mathrm{L}$ & 1 & & 1.38 & \\
\hline & & W & 1 & & 1.21 & \\
\hline & CBR0C & $\mathrm{L}$ & 1 & & 1.15 & \\
\hline & & W & 1 & & 1.15 & \\
\hline \multirow[t]{7}{*}{ M1 } & MCX3 & $\mathrm{L}$ & 1 & & 1.47 & \\
\hline & FS1 & $\mathrm{L}$ & 1 & & 1.31 & \\
\hline & & $\mathrm{W}$ & 1 & & 1.58 & \\
\hline & MAB3 & $\mathrm{L}$ & 2 & 1.44 & 1.47 & 1.51 \\
\hline & & W & 1 & & 1.87 & \\
\hline & MAB5 & $\mathrm{L}$ & 1 & & 1.41 & \\
\hline & & W & 1 & & 1.55 & \\
\hline \multirow[t]{2}{*}{ M2 } & MAB3 & $\mathrm{L}$ & 3 & 1.40 & 1.44 & 1.49 \\
\hline & & $\mathrm{W}$ & 2 & 1.66 & 1.67 & 1.68 \\
\hline
\end{tabular}

\begin{tabular}{|c|c|c|c|c|}
\hline \multicolumn{5}{|c|}{ Atlantoxerus blacki } \\
\hline \multirow[t]{2}{*}{$\mathrm{d} 4$} & MAB3 & $\mathrm{L}$ & 1 & 1.74 \\
\hline & & W & 1 & 1.37 \\
\hline \multirow[t]{2}{*}{ p4 } & MAB3 & $\mathrm{L}$ & 1 & 1.43 \\
\hline & & W & 1 & 1.32 \\
\hline \multirow[t]{2}{*}{$\mathrm{m} 1$} & MAB5 & $\mathrm{L}$ & 1 & 2.44 \\
\hline & & W & 1 & 2.07 \\
\hline M3 & MAB5 & W & 1 & 2.44 \\
\hline
\end{tabular}

\begin{tabular}{|c|c|c|c|c|}
\hline M3 & MAB5 & W & 1 & 2.44 \\
\hline \multicolumn{5}{|c|}{ Aragoxerus sp. } \\
\hline \multirow[t]{3}{*}{ p4 } & CBR0B & $\mathrm{L}$ & 1 & $>1$ \\
\hline & & W & 1 & $>0.71$ \\
\hline & CBR1 & $\mathrm{W}$ & 1 & 0.84 \\
\hline \multicolumn{5}{|c|}{ Marmotini indet. } \\
\hline \multirow[t]{2}{*}{ I } & MAB3 & $\mathrm{L}$ & 1 & 3.6 \\
\hline & & $\mathrm{W}$ & 1 & 1.59 \\
\hline \multicolumn{5}{|c|}{ Palaeosciurus cf. sutteri } \\
\hline \multirow[t]{2}{*}{$\mathrm{M} 1 / 2$} & MAB3 & $\mathrm{L}$ & 1 & 2.64 \\
\hline & & $\mathrm{W}$ & 1 & 3.00 \\
\hline \multicolumn{5}{|c|}{ Spermophilinus sp. } \\
\hline $\mathrm{m} 1 / \mathrm{m} 2$ & & $\mathrm{~W}$ & 1 & 1.49 \\
\hline \multicolumn{5}{|c|}{ Aliveria cf. luteyni } \\
\hline
\end{tabular}

Remarks. - This fragment of tooth belongs to a small ground squirrel, with characteristics not observed in the studied material of other taxa in the Ribesalbes-Alcora Basin. Examples are the very high anteroconulid or the long and sigmoidal metalophid, which is connected to the crest that links the protoconid to the hypoconid.

This morphology appears in Spermophilinus aff. bredai (von Meyer, 1848) from Forsthart, described by Ziegler \& Fahlbusch (1986, fig. 4.5), although the contact between the anteroconulid and the protoconid is better developed in the material studied here. This character distinguishes our tooth from Spermophilinus besanus Cuenca-Bescós, 1988 of the Calatayud-Montalbán Basin (Cuenca-Bescós 1988). The occurrence of a complete metalophid distinguishes S. besanus from Spermophilinus minutus Zheng \& Li, 1982, where the metalophid is residual. Nevertheless, this character is similar in $S$. bredai, where the metalophid could be complete (Zheng \& Li 1982, Cuenca-Bescós 1988).

Morphometrically, the tooth studied here is situated in the lower part of the variability range of the $\mathrm{m} 1$ of $S$. aff. bredai from Forsthart and La Grive, or of S. minutus (Zheng \& Li 1982, Ziegler \& Fahlbusch 1986), and it is clearly smaller than in S. besanus, S. bredai, Spermophilinus turolensis de Bruijn \& Mein, 1968 and Spermophilinus giganteus de Bruijn, Dawson \& Mein, 1970 (CuencaBescós 1988, de Bruijn 1995, Vasileiadou \& Koufos 2005).

Although the closest taxon seems to be $S$. aff. bredai from Central Europe, the observed differences and the scarcity and preservation state of the recovered material prevents us to assign it to a particular species.

Occurrence. - Mas d'Antolino B 5 (MAB5).

Subfamily Pteromyinae Brandt, 1855

\section{Genus Aliveria de Bruijn, Van der Meulen \& Katsikatsos, 1980}

\section{Aliveria cf. luteyni de Bruijn, Van der Meulen \& Katsikatsos, 1980}

Figure 3M

Material. - CBR0B - $1 \mathrm{~m} 1 / 2$.

Measurements. - See Tab. 1.

Description. $-\mathrm{m} 1 / 2$ (Fig. 3M): A broken tooth with a subquadrangular outline. The surface of the enamel is wrinkled. The anteroconulid is small and connected to the protoconid by a short anterior cingulid. The anterolophid is bulbous. The metalophid is incomplete and not connected to the metaconid. The mesoconid is well developed and 
sigmoidally connected with the hypoconid. The entoconid is an enlargement of the posterolophid, which is curved and has a bulbous-shape.

Remarks. - CBR0B is the only site that has yielded a fragmented tooth morphologically attributable to a flying squirrel. This tooth is characterized by the anterior cingulid, three well-developed cuspids and a posterolophid with conulids. These features are present in Aliveria luteyni from Rembach (Germany); this population was assigned to Forsythia aff. gaudryi Mein, 1970 by Ziegler \& Fahlbusch (1986), but later, de Bruijn (1999) assigned the specimens to Aliveria luteyni. Furthermore, these features make this species clearly distinct from Miopetaurista $\mathrm{cf}$. dehmi de Bruijn, Van der Meulen \& Katsikasos, 1980 from Forsthart (Ziegler \& Fahlbusch 1986). Overall, the studied tooth differs from Miopetaurista neogrivensis in its smaller size (Aldana-Carrasco 1992) and particularly, from Miopetaurista diescalidus Daams, 1977, which has a very wrinkled enamel and a small mesoconid (Daams 1977), while our tooth shows a slightly wrinkled enamel and a well-developed mesoconid. Besides, the welldeveloped anteroconulid makes this tooth clearly distinct from the genera Albanensia and Forsythia. Therefore, the genus most similar to the material from CBR0B is Aliveria (de Bruijn et al. 1980). At the species level, the absence of the entolophid is characteristic of the species Aliveria luteyni, as in the populations from Aliveri and the German sites of Rembach and Erkertshofen (de Bruijn et al. 1980, Ziegler \& Fahlbusch 1986). In regard to the size, the tooth here described can be included, like the genus Aliveria, in the group of the middle-sized Pteromiynae (Daxner-Höck 2004).

Due to the aforementioned reasons and the scarcity of the material, we have left this tooth as Aliveria cf. luteyni, which constitutes the first cite of the genus Aliveria in Western Europe. Furthermore, this is probably one of the oldest representatives of the true flying squirrels in the fossil record (de Bruijn et al. 1980, Thorington et al. 2005, Casanovas-Vilar et al. 2018). We include Aliveria in the Pteromyinae after McKenna \& Bell (1997).

Occurrence. - Corral de Brisca 0B (CBR0B).

\section{Discussion}

\section{Biostratigraphy}

The use of squirrels as biostratigraphic markers is well established (Cuenca-Bescós 1988; and references therein). Although, their low abundance in the Ribesalbes-Alcora Basin prevented us to use them as such, they show a high diversity along the studied sections (Tab. 2).
Table 2. Percentages of frequency (\%) of squirrels found in the Araia sections. Only sites with more than 45 teeth are represented, the number in parentheses next to the locality name represents the number of mammal teeth found at the site (modified from Crespo et al. 2019a).

\begin{tabular}{lcc}
\hline Locality & Squirrels & Rest of rodents \\
\hline CBR1 (47) & 2.1 & 74.6 \\
CBR0B (56) & 9 & 64.3 \\
MAB11 (145) & 0.7 & 62.2 \\
MAB5 (874) & 0.5 & 69.8 \\
MAB3 (807) & 2.5 & 76.8 \\
FS1 (63) & 6.3 & 84.1 \\
MAB0B (75) & 0 & 38.7 \\
MAB0A (80) & 0 & 90.2 \\
BC1 (180) & 3.3 & 74.9 \\
MTR2 (187) & 0.5 & 64 \\
MCX3 (132) & 2.3 & 71.2 \\
\hline
\end{tabular}

Heteroxerus rubricati is the most abundant squirrel (Tab. 2) in the studied basin, but also in the contemporaneous sites in the Iberian Peninsula. Its temporal range extends between the early and the upper Miocene (MN2-9) (Fortelius 2016). After Cuenca-Bescós (1988), GarcíaParedes et al. (2016) and Van der Meulen et al. (2012) in the Calatayud-Montalbán Basin its stratigraphic range starts in the Ramblian and ends at the top of the local zone G1 (MN6, Aragonian, middle Miocene). In the VallèsPenedès Basin, it is very abundant in the MN4 and its last occurrence is in the upper Miocene, in the early Vallesian (MN9; Aldana-Carrasco 1992, Jovells-Vaquè et al. 2018). In the Magro Basin it appears in the sites Barranco de Candel and Buñol (Adrover et al. 1987, Robles et al. 1991) and almost all of the Morteral series (Ruiz-Sánchez et al. 2003). Finally, this species is present along the whole middle Miocene record of the Madrid Basin (HernándezBallarín \& Peláez-Campomanes 2018).

The stratigraphic range of the species Atlantoxerus blacki is more restricted. In the Calatayud-Montalbán Basin it extends between the local biozones B (MN4, Aragonian, early Miocene) and Dc (MN5, Aragonian, early Miocene) (Van der Meulen et al. 2012), thus shortening the record given by Cuenca-Bescós (1988). In the Vallès-Penedès Basin this species is limited to the MN4 (Aragonian, early Miocene; Aldana-Carrasco1992) and to the local biozone Dc in the Madrid Basin (MN5, middle Miocene; Hernández-Ballarín \& Peláez-Campomanes 2018).

The genus Aragoxerus has been described in MN3 of the Calatayud-Montalbán Basin (Cuenca-Bescós 1988), and it appears later in MN4-6 in France (Aguilar 2002); its last record is in Crevillente 2 (MN11, Turolian, upper Miocene; Mazo \& Montoya 2003; and references therein). 
The species Palaeosciurus sutteri is typical for Central and Southwestern Europe and Turkey, with a temporal range that starts in MN4 and ends in MN6 (early - middle Miocene; de Bruijn 1999, Prieto et al. 2017, Bosma et al. 2018). The occurrence of this species in the RibesalbesAlcora Basin constitutes its first record in the Iberian Peninsula, and one of the last records of this genus in the same geographic zone. In the Calatayud-Montalbán Basin Palaeosciurus appeared at the end of the Agenian (Cuenca-Bescós 1988) and, according to García-Paredes et al. (2016), it became extinct in the Ramblian (local zone A, MN3, early Miocene). In the Vallès-Penedès Basin it has only been recorded, as $P$. aff. fissurae, in MN4 of the locality of San Mamet (Aldana-Carrasco 1992).

The genus Spermophilinus has a wide biostratigraphic record (de Bruijn 1999). In the Calatayud-Montalbán Basin, S. besana extends from the middle of the local zone B (MN4, early Miocene) until the middle of the local zone Dc (MN5, middle Miocene; Van der Meulen et al. 2012). In the early Miocene, in the Vallès-Penedès Basin, Spermophilinus only occurs in the site of Els Casots (MN4, early Miocene; Aldana-Carrasco 1992). Finally, in the Magro Basin, this genus is cited as $S$. bredai in Buñol (local zone C, MN4, early Miocene; Robles et al. 1991).

The flying squirrel Aliveria luteyni was described in the Greek locality of Aliveri, and was later reported in Karydia (also in Greece), both in the MN4 (early Miocene; de Bruijn et al. 1980, Doukas 2003). This taxon has also been found in other localities from Germany, Turkey and Serbia (here as $A$. aff. luteyni) with a similar age (de Bruijn 1999, Marković et al. 2016, Bosma et al. 2018). The record from the Ribesalbes-Alcora Basin is the first one for this genus in Western Europe. Probably, this genus originated in Turkey, where it shows a longer stratigraphic range, from the MN3 to the MN5 (early-middle Miocene; Kaya et al. 2007).

\section{Palaeoecology}

The genera Atlantoxerus and Heteroxerus are typical of warm and dry climates. Atlantoxerus has an extant representative (Barbary ground squirrel, A. getulus) that lives in African deserts (Van Dam \& Weltje 1999, MinwerBarakat 2005, García-Alix et al. 2008, Mansino et al. 2018). According to Minwer-Barakat (2005) and GarcíaAlix et al. (2008) these genera are associated to open and denuded environments, and Menéndez et al. (2017) have reported the species $H$. rubricati in the semidesertic habitat of the site Somosaguas in the Madrid Basin. Aragoxerus might have shared these preferences, although there is no literature on this topic, but Cuenca-Bescós (1988) or Denys et al. (2003), among others, include this genus in the Xerini, that generally have a similar life style. The ground squirrel Heteroxerus is the most abundant squirrel in the sites in study (Tab. 2).

The marmotine Palaeosciurus is a typical dweller of open to partially open habitats, similar to the ground squirrels in behaviour (Costeur et al. 2012). More specifically, the species Palaeosciurus goti has been described as a fossorial animal (Ginot et al. 2016), although this taxon would have no specific humidity or temperature requirements.

The other ground squirrel, Spermophilinus, lived in well illuminated woods interspersed with open herbaceous zones (Lungu 1981, Nicoara 2011), or in open habitats (Prieto et al. 2014). However, after an analysis of the dental microwear, Gusovsky \& Sinitsa (2019) suggested that "the members of this genus were related to closed, forested biomes, where they consumed hard fruits, nuts, tree seeds and, rarely, insects, somewhat like many living arboreal squirrels do today". Spermophilinus has been found throughout all Europe, which suggests that it had no specific temperature or humidity preferences.

The genus Aliveria probably represents one of the first gliding squirrels (de Bruijn et al. 1980). Different morphological characteristics (such as the convergent protoloph and metaloph, wrinkled enamel...) suggest they are convergent with the current flying squirrels. This is questioned by Thorington et al. (2005) and Thorington \& Santana (2007), because these features appear in basal members of the group, next to the genus Glaucomys, and the group of Petaurista. These authors show that these adaptations may result from a folivorous diet, and do not constitute an adaptation to flight. However, Casanovas-Vilar et al. (2018) consider the group of the Pteromyini (including Glaucomyina) as monophyletic and adapted to glide. In the other hand, newer data suggest that this group has a monophyletic origin in the late Eocene (with the genus Hesperopetes) or in the early Oligocene (with the genus Oligopetes) due to, these genera have a typical flying squirrel dental pattern (Heissig 1979, de Bruijn \& Unay 1989, Korth 2017). Even so, this fact indicates a more or less closed wooded habitat, and this is widely accepted in the literature (Cuenca-Bescós 1988, de Bruijn 1999, Van Dam \& Weltje 1999, García-Alix et al. 2008, CasanovasVilar et al. 2015). Furthermore, Van Dam \& Weltje (1999) attribute wet preferences to the Pteromyini. DaxnerHöck (2004) classifies the flying squirrels in three groups according to their size, including Aliveria in the middle-size group. This author highlights some forms tolerant to dry conditions (as the genus Hylopetes) or others that dwell in evergreen boreal or mixed woods (as the genus Pteromys).

The genera Aliveria, Spermophilinus, Palaeosciurus and the Marmotini indet. have been found in only one site, and therefore they can be considered as transient stenotopic taxa, while Heteroxerus and Atlantoxerus that appear more frequently in the sites in study (Tab. 2) were resilient and eurytopic. 


\section{Conclusions}

The Ribesalbes- Alcora Basin, with continental sequences similar in age to those of the Calatayud-Montalbán area (local biozones $\mathrm{Ca}$ and $\mathrm{Cb}, \mathrm{MN} 4$, early Miocene), has yielded a relatively diverse fauna of squirrels. The most abundant is the ground squirrel Heteroxerus rubricati and to a lesser degree Atlantoxerus blacki and Aragoxerus sp., the marmotine Palaeosciurus cf. sutteri, Spermophilinus sp., and Marmotini indet. and the flying squirrel Aliveria cf. luteyni. Heteroxerus rubricati, Atlantoxerus blacki and Spermophilinus are typical species from the Iberian early Miocene faunas. Aragoxerus is reported for the first time in the MN4 of the Iberian Peninsula, and together with the French record, it is the only cite from Europe. The species Palaeosciurus cf. sutteri, typical from Central and Southeastern Europe and from Turkey, constitutes the first record of this species, if it is confirmed, in the Iberian Peninsula, and one of the oldest in Europe. The occurrence of Aliveria cf. luteyni also constitutes the first record of Aliveria in Western Europe. The presence of a high diversity of squirrels, despite their low proportion when compared to other rodents, is indicative of the richness of habitats in the paleolake that filled the Ribesalbes-Alcora Basin in the early Miocene. The dominance of Heteroxerus rubricati and Atlantoxerus blacki, in lesser proportion, together with other species with humid preferences (Crespo 2017; Crespo et al. 2018, 2019a, b, c, 2020), indicates that these species were more eurytopic than previously thought.

\section{Acknowledgments}

The survey and excavation campaigns in the area of Araia d'Alcora were funded by the Conselleria de Cultura i Esports of the Generalitat Valenciana from 2008 to 2011, by projects 2008/0433-CS, 2010/0528-CS, 2011/0230-CS, GV06/304 and GVPRE/2008/320. This research was also supported by the Spanish Ministerio de Ciencia, Innovación y Universidades PGC2018-094122-B100 (AEI/ FEDER, UE). Thanks are also due to the helpful comments of J. Guillem, T. Mörs and anonymous reviewers on the original manuscript. V.D.C is beneficiary of a postdoctoral fellowship from the Argentinian Consejo Nacional de Investigaciones Científicas y Técnicas (CONICET).

\section{References}

Adrover, R., Mein, P. \& Belinchón, M. 1987. La fauna de roedores en el Aragoniense medio del Barranco del Candel, Buñol (provincia de Valencia, España). Paleontologia i evolució 21, 43-61.

Aguilar, J.P. 2002. Les sciuridés des gisements karstiques du Miocène Inférieur à Moyen du sud de la France: nouvelles espèces, phylogénie, paléoenvironnement. Geobios 35, 375-394. DOI 10.1016/S0016-6995(02)00033-5

Agustí, J., Anadón, P., Ginsburg, L., Mein, P. \& Moissenet, E. 1988. Araya et Mira: nouveaux gisements de mammifères dans le Miocène Infèrieur-Moyen des Chaînes Ibériques orientales et méditerranéennes. Conséquences stratigraphiques et structurales. Paleontologia i evolució 22, 83-101.

Aldana-Carrasco, E.J. 1992. Los Sciurinae (Rodentia, Mammalia) del Mioceno de la Cuenca del Vallès-Penedès (Cataluña, España). Treballs del Museu de Geologia de Barcelona 2, 69-97.

AnAdón, P. 1983. Características generales de diversas cuencas lacustres terciarias con pizarras bituminosas del NE de la Península Ibérica. Comunicaciones del X Congreso Nacional de Sedimentología 1, 9-12.

Black, C.C. 1965. New species of Heteroxerus (Rodentia, Sciuridae) in the French Tertiary. Verhandlungen der Naturforschenden Gessellschaft in Basel 76, 185196.

Bosma, A.A., Bruijn, H. DE \& Wessels, W. 2013. Late Miocene Sciuridae (Mammalia, Rodentia) from Anatolia, Turkey. Journal of Vertebrate Paleontology 33, 924-942. DOI 10.1080/02724634.2013.755990

Bosma, A.A., Bruijn, H. De \& Wessels, W. 2018. Early and middle Miocene Sciuridae (Mammalia, Rodentia) from Anatolia, Turkey. Journal of Vertebrate Paleontology 38, e1537281. DOI 10.1080/02724634.2018.1537281

Bowdich, T.E. 1821. An Analysis of the Natural Classifications of Mammalia for the Use of Students and Travellers. $115 \mathrm{pp}$. J. Smith, Paris.

BRANDT, J.F. 1855. Untersuchungen über die craniologischen Entwicklungsstufen und Classification der Nager der Jetzwelt. Mémories de l'Académie Imperiale des Sciences de Saint Pétersbourg Série 6 9, 1-365.

BRUiJn, H. de 1967. Gliridae, Sciuridae y Eomyidae (Rodentia, Mammalia) miocenos de Calatayud (Prov. Zaragoza, Espagne) y su relación con la bioestratigrafía del área. Boletín del Instituto Geológico y Minero de España 78, 187-373.

BruiJn, H. DE 1995. Sciuridae, Petauristidae and Eomyidae (Rodentia, Mammalia), 87-102. In Schmidt-Kittler, N. (ed.) The vertebrate locality Maramena (Macedonia, Greece) at the Turolian-Ruscinian Boundary (Neogene). Münchner Geowissenschaftliche Abhandlungen A 28.

BRUiJn, H. DE 1999. Superfamily Sciuroidea, 271-280. In RösSNER, G.E. \& Heissig, K. (eds) The Miocene Land Mammals of Europe. Verlag Dr. Friedrich Pfeil, München.

Bruisn, H. DE \& MeIn, P. 1968. On the mammalian fauna of the Hipparion-beds in the Calatayud Teruel Basin (Prov. Zaragoza, Spain). Part V. The Sciurinae. Proceedings of the Koninklijke Nederlandse Akademie van Wetenschappen Series B 71, 73-90.

Bruijn, H. DE \& Moltzer, J.G. 1974. The rodents from Rubielos de Mora: the first evidence of the existence of different biotopes in the Early Miocene of eastern Spain. Proceedings Koninklijke Nederlandse Akademie van Wetenschappen, B 77 , 129-145.

Bruijn, H. DE \& Unay, E. 1989. Petauristinae (Mammalia, Rodentia) from the Oligocene of Spain, Belgium and Turkish 
Thrace. Natural History Museum of Los Angeles County, Science Series 33, 139-146.

Bruijn, H. De, Dawson, M.R. \& Mein, P. 1970. Upper Pliocene Rodentia, Lagomorpha and Insectivora (Mammalia) from the isle of Rhodes (Greece). III. The Rodentia, Lagomorpha and Insectivora. Proceedings of the Koninklijke Nederlandse Akademie van Wetenschappen Series B 73, 568-584.

Bruijn, H. de, Van der Meulen, A.J. \& Katsikatsos, G. 1980. The mammals from the lower Miocene of Aliveri (Island of Evia, Greece) Part I. The Sciuridae. Proceedings of the Koninklijke Nederlandse Akademie van Wetenschappen, Serie B 83, 241-261.

CArus, J.V. 1868. Handbuch der Zoologie. 1. Wirbelthiere, Mollusken, und Molluscoiden. 894 pp. Verlag von Wilhelm Engelmann, Leipzig.

Casanovas-Vilar, I., Almécija, S. \& Alba, D.M. 2015. Late Miocene flying squirrels from Can Llobateres 1 (Vallès-Penedès Basin, Catalonia): systematics and palaeobiogeography. Palaeobiodiversity and Palaeoenvironments 95(3), 353-372. DOI 10.1007/s12549-015-0192-1

Casanovas-Vilar, I., Madern, A., Alba, D.M., Cabrera, L., García-Paredes, I., Van den Hoek Ostende, L.W., Demiguel, D., Robles, J.M., Furió, M., Van Dam, J., Garcés, M., Angelone, C. $\&$ Moỳ̀-SolÀ, S. 2016. The Miocene mammal record of the Vallès-Penedès Basin (Catalonia). Comptes Rendus Palevol 15(7), 791-812. DOI 10.1016/j.crpv.2015.07.004

Casanovas-Vilar, I., Garcia-Porta, J., Fortuny, J., Sanisidro, O., Prieto, J., Querejeta, M., Llácer, S., Robles, J.M., Bernardini, F. \& Alba, D.M. 2018. Oldest skeleton of a fossil flying squirrel casts new light on the phylogeny of the group. eLife 7, e39270. DOI 10.7554/eLife.39270

Churakov, G., Sadasivuni, M.K., Rosenbloom, K.R., Huchon, D., Brosius, J. \& Schmitz, J. 2010. Rodent evolution: back to the root. Molecular Biology and Evolution 27, 1315-1326. DOI 10.1093/molbev/msq019

Costeur, L., Maridet, O., Peigné, S. \& Heizmann, E.P. 2012. Palaeoecology and palaeoenvironment of the Aquitanian locality Ulm-Westtangente (MN2, Lower Freshwater Molasse, Germany). Swiss Journal of Palaeontology 131(1), 183-199. DOI 10.1007/s13358-011-0034-3

CRespo, V.D. 2017. Los mamíferos del Mioceno Inferior de la Cuenca de Ribesalbes Alcora (Castelló, España). 695 pp. $\mathrm{Ph}$.D. thesis. Universitat de València, Valencia, Spain.

Crespo, V.D., Furió, M., Ruiz-SÁnchez, F.J. \& Montoya, P. 2018. A new species of Plesiodimylus (Dimylidae, Eulipotyphla, Mammalia) from the early Miocene of Spain. Historical Biology 30, 360-371. DOI 10.1080/08912963.2017.1289519

Crespo, V.D., Suárez-Hernando, O., Murelaga, X., RuizSÁnchez, F.J. \& Montoya, P. 2019a. Early Miocene mammal assemblages from the Campisano ravine in the RibesalbesAlcora Basin (E Spain). Journal of Iberian Geology 45, 181-194. DOI 10.1007/s41513-018-0093-Z

Crespo, V.D., Marquina-Blasco, R., Ruiz-Sánchez, F.J. \& Montoya, P. 2019b. An unusual insectivore assemblage from the early Miocene of southwestern Europe: the talpids and dimylids from the Ribesalbes-Alcora Basin (Spain). Comptes Rendus Palevol 18, 407-416.

DOI 10.1016/j.crpv.2019.03.003
Crespo, V. D., Fagoaga, A., Montoya, P. \& Ruiz-Sánchez, F.J. 2019c. Old-timers and newcomers: The shrews and heterosoricids from the Ribesalbes-Alcora Basin (East of Spain). Palaeontologia Electronica 22.3.64, 1-22. DOI 10.26879/999

Crespo, V.D., Goin, F.J., Montoya, P. \& Ruiz-Sánchez, F.J. 2020. Early Miocene marsupialiforms, gymnures and hedgehogs from southernmost Western Europe. Journal of Paleontology 94(6), 1213-1227. DOI 10.1017/jpa.2020.58

Crusafont, M., Villalta, J.F., \& Truyols, J. 1955. El Burdigaliense continental de la cuenca del Vallés-Penedés. Memorias y Comunicaciones del Instituto Geológico 12, 1-273.

Cuenca-Bescós, G. 1986. Heteroxerus ignis n. sp. (Sciuridae, Rodentia, Mammalia) from the lower Miocene of Spain. Casopis pro Mineralogii a Geologi 31, 131-142.

Cuenca-Bescós, G. 1988. Revisión de los Sciuridae del Aragoniense y del Rambliense en la fosa de Calatayud-Montalbán. Scripta Geologica 87, 1-116.

DaAms, R. 1977. Aragonian Sciuroptera (Sciuridae, Rodentia, Mammalia) from Spain. Proceedings of the Koninklijke Nederlandse Akademie van Wetenschappen, Serie B 80, 356-359.

DAXNer-Höck, G. 2004. Flying squirrels (Pteromyinae, Mammalia) from the Upper Miocene of Austria. Annalen des Naturhistorischen Museums in Wien, Serie A 106, 387-423.

Denм, R. 1950. Die Nagetiere aus dem Mittel-Miocän (Burdigalium) von Wintershof-West bei Eichstätt in Bayern. Neues Jahrbuch für Mineralogie, Geologie und Paläontologie, Abhandlungen B 91, 321-428.

Denys, C., Viriot, L., Daams, R., Peláez-Campomanes, P., Vignaud, P., Andossa, L. \& Brunet, M. 2003. A new Pliocene xerine sciurid (Rodentia) from Kossom Bougoudi, Chad. Journal of Vertebrate Paleontology 23(3), 676-687. DOI $10.1671 / 2311$

Doukas, C.S. 2003. The MN4 faunas of Aliveri and Karydia (Greece), 127-132. In LóPez-Martínez, N., PelÁez-CAMPoMANES, P. \& HernáNDEZ-Fernández, M. (eds) En torno a fósiles de mamíferos: datación, evolución y paleoambiente, Volumen en Honour de Remmert Daams. Coloquios de Paleontología Número Extraordinario 1.

FISCHER, G. 1817. Adversaria Zoologica, fasciculus primus. Mémoires de la Société des Naturalistes de Moscou 5, 357-446.

Forsyth Major, C.J. 1893. On some Miocene Squirrels, with remarks on the Dentition and Classification of the Sciurinae. Proceedings of Zoological Society of London, 179-215.

ForTelius, M. (coordinador) 2016. New and Old Worlds Database of Fossil Mammals (NOW). University of Helsinki. http:// www.helsinki.fi/science/now/

Furió, M., Ruiz-Sánchez, F.J., Crespo, V.D., Freudenthal, M. \& Montoya, P. 2012. The southernmost Miocene occurrence of the last European herpetothetiid Amphiperatherium frequens (Metatheria, Mammalia). Comptes Rendus Palevol 11, 371-377. DOI 10.1016/j.crpv.2012.01.004

García-Alix, A., Minwer-Barakat, R., Martín-Suárez, E., FReudenthal, M. \& Martín, J.M. 2008. Late Miocene-Early Pliocene climatic evolution of the Granada Basin (southern Spain) deduced from the paleoecology of the micromammal 
associations. Palaeogeography, Palaeoclimatology, Palaeoecology 265, 214-225. DOI 10.1016/j.palaeo.2008.04.005

García-Paredes, I., Álvarez-Sierra, M.Á., Van den Hoek Ostende, L.W., Hernández-Ballarín, V., HordiJk, K., LópezGuerrero, P., Oliver, A. \& Peláez-Campomanes, P. 2016. The Aragonian and Vallesian high-resolution micromammal succession from the Calatayud-Montalbán Basin (Aragón, Spain). Comptes Rendus Palevol 15, 781-789.

DOI 10.1016/j.crpv.2015.09.014

Ginot, S., Hautier, L., Marivaux, L. \& Vianey-Liaud, M. 2016. Ecomorphological analysis of the astragalo-calcaneal complex in rodents and inferences of locomotor behaviours in extinct rodent species. PeerJ 4, e2393. DOI 10.7717/peerj.2393

Gusovsky, V.V. \& Sinitsa, M.V. 2019. Dietary preferences and autecology of a basal Holarctic ground squirrel Spermophilinus (Rodentia: Sciuridae: Xerinae), inferred from dental microwear analysis. Historical Biology, 1-8.

DOI 10.1080/08912963.2019.1677641

Heissig, K. 1979. Die frühesten Flughörnchen und primitive Ailuravinae (Rodentia, Mammalia) aus dem süddeutschen Oligozän. Mitteilungen der Bayerischen Staatssammlung für Paläntologie und historische Geologie 19, 139-169.

Hernández-Ballarín, V. \& Peláez-Campomanes, P. 2018. Updated biochronology of the Madrid Basin: species distribution and implications for the Middle Miocene rodent faunas of Spain. Historical Biology 30, 305-316.

DOI 10.1080/08912963.2016.1276580

Hordij,, K., Bosma, A., Bruijn, H. de, Van Dam, J., Geraedts, C., Van den Hoek Ostende, L.W., Reumer, J. \& Wessels, W. 2015. Biostratigraphical and palaeoecological implications of the small mammal assemblage from the late Early Miocene of Montalvos2, Teruel Basin, Spain. Palaeobiodiversity and Palaeoenvironments 95, 321-346.

DOI 10.1007/s12549-015-0203-2

Hugueney, M. \& Bulot, C. 2011. Les petits Mammifères du Burdigalien (MN3; Miocène) d'Estrepouy (Gers, France): liste faunique actualisée. Estudios Geológicos 67, 427-442. DOI 10.3989/egeol.40584.200

Kaya, O., Ünay, E., Göktaș, F. \& Saraç, G. 2007. Early Miocene stratigraphy of Central West Anatolia, Turkey: implications for the tectonic evolution of the Eastern Aegean area. Geological Journal 42, 85-109. DOI 10.1002/gj.1071

Korth, W.W. 2017. First record of Hesperopetes Emry and Korth, 2007 (Rodentia, Sciuridae), from the Orellan (early Oligocene). Journal of Vertebrate Paleontology 37, e1318890. DOI 10.1080/02724634.2017.1318890

Krystufek, B., Mahmoudi, A., Tesakov, A.S., Mateju, J. \& Hutterer, R. 2016. A review of bristly ground squirrels Xerini and a generic revision in the African genus Xerus. Mammalia 80, 521-540. DOI 10.1515/mammalia-2015-0073

Jovells-Vaqué, S., García-Paredes, I., Furió, M., Angelone, C., Van den Hoek Ostende, L.W., Berrocal Barberà, M., Demiguel, D., Madurell-Malapeira, J. \& Casanovas-Vilar, I. 2018. Les Cases de la Valenciana, a new early Miocene smallmammal locality from the Vallès-Penedès Basin (Catalonia, Spain). Historical Biology 30, 404-421.

DOI 10.1080/08912963.2017.1317768
LARTEt, E. 1851. Notice sur la colline de Sansan, suivie d'une récapitulation des diverses espèces d'animaux vertébrés fossiles, trouvés soit à Sansan, soit dans d'autres gisements du terrain tertiaire du miocène dans le bassin sous-pyrénéen. JA Portes 1, 1-47.

Linnaeus, C. 1758. Systema Naturae, Per Regna Tria Naturae, Secundum Classes, Ordines, Genera, Species cum Characteribus, Differentis Synonymis, Locus. Salvii, [Sotck] Holmiae 1, 1-824. DOI 10.5962/bhl.title.542

Lungu, A. 1981. Gipparionovaia fauna srednego Sarmata Moldavii (Insectivora, Lagomorpha, Rodentia). 140 pp. Izdatelistvo Shtiintsa, Kisinev.

McKenna, M.C. \& BeLL, S.K. 1997. Classification of Mammals Above the Species Level. 631 pp. Columbia University Press, New York.

Mansino, S., Ruiz-Sanchez, F.J. \& Montoya, P. 2018. Sciuridae (Rodentia, Mammalia) from the Late Miocene of Venta del Moro (Cabriel Basin, Spain): biostratigraphical, phylogenetic and palaeoecological inferences. Historical Biology 30, 297-304. DOI 10.1080/08912963.2016.1242583

Marković, Z., Bruijn, H. de \& Wessels, W. 2016. A revision of the new rodent collections from the Early Miocene of Sibnica, Serbia, 63-117. In Marković, Z. \& Milivojević, M. (eds) Life on the Shore: Geological and Paleontological Research in the Neogene of Sibnica and Vicinity (Levač basin, Central Serbia). Part 1. Special Issue of the Natural History Museum in Belgrade. Natural History Museum, Belgrade.

Mazo, A.V. \& Montoya, P. 2003. Proboscidea (Mammalia) from the Upper Miocene of Crevillente (Alicante, Spain). Scripta Geologica 126, 79-109.

MeIN, P. 1970. Les sciuropteres (Mammalia, Rodentia) neogenes d'Europe occidentale. Geobios 3, 7-77.

DOI 10.1016/S0016-6995(70)80001-8

Menéndez, I., Gómez Cano, A.R., García Yelo, B.A., Domingo, L., Domingo, M.S., Cantalapiedra, J.L., Blanco, F. \& HerNÁNDEZ-FERNÁNDEZ, M. 2017. Body-size structure of Central Iberian mammal fauna reveals semidesertic conditions during the middle Miocene Global Cooling Event. PLoS ONE 12, e0186762. DOI 10.1371/journal.pone.0186762

Meyer, H. von 1846. Mittheilungen an Professor Bronn. Neues Jahrbuch für Mineralogie, Geognosie, Geologie und Petrefakten-Kunde 1846, 462-476.

Meyer, M. von 1848. Mittheilungen an Professor Bronn gerichtet. Frankfurt am Main. Neues Jahrbuch für Mineralogie, Geognosie, Geologie, und Petrefaktenkunde 1848, 465-473.

MinWER-BARAKAT, R. 2005. Roedores e insectívoros del Turoliense superior y el Plioceno del sector central de la Cuenca de Guadix. 548 pp. Ph.D. thesis, Universidad de Granada, Granada, Spain.

Moore, J.C. 1959. Relationship among the living squirrels of the Sciurinae. Bulletin of the American Museum of Natural History 118,159-206.

Murray, A. 1866. The geographical distribution of mammals. 420 pp. Day \& Son Ltd., London. DOI 10.5962/bhl.title. 15762

Nicoara, I. 2011. Upper Turolian sciuroidea (Rodentia, Mammalia) from the Republic of Moldova. Acta Palaeontologica Romaniae 7, 257-265.

Osborn, H.F. 1910. The Age of Mammals in Europe, Asia and North America. 635 pp. Macmillan Co., New York.

DOI 10.5962/bhl.title.102077 
Peláez-Campomanes, P. 2001. Revision of the Aragonian (Miocene) Atlantoxerus (Sciuridae). Journal of Paleontology $75,418-426$.

DOI 10.1666/0022-3360(2001)075<0418:ROTAMA >2.0.CO;2

Pocock, R.I. 1923. The classification of the Sciuridae. Proceedings of the Zoological Society of London 93, 209-246. DOI 10.1111/j.1096-3642.1923.tb02184.x

Pomel, N.A. 1853. Catalogue methodique et descriptif des vertebres fossiles decouverts dans les bassins de la Loire et de l'Allier (suite et fin). Annales Scientifiques, Litteraires et Industrielles de l'Auvergne 26, 81-229.

Prieto, J., Angelone, C., Casanovas-Vilar, I., Gross, M., Hír, J., Van den Hoek Ostende, L.W., Maul, L.C. \& Vasilyan, D. 2014. The small mammals from Gratkorn: an overview. Palaeobiodiversity and Palaeoenvironments 94, 135-162. DOI 10.1007/s12549-013-0147-3

Prieto, J., Peláez-Campomanes, P. \& Scholz, H. 2017. Sciurids (Rodentia, Mammalia) from Höll (Middle Miocene, Bavaria). Zitteliana 89, 351-354.

Robles, F., Belinchón, M., García-Flor, J. \& Morales, J. 1991. El Neógeno continental de Buñol y del valle del río Cabriel. Revista Española de Paleontología, Special Issue, 205-215.

Ruiz-Sánchez, F.J., SAntisteban, C. De \& Lacomba, J.I. 2003. Nuevas faunas de roedores fósiles (Mammalia, Rodentia) de edad Aragoniense inferior y medio en la serie del Barranco de Morteral (cuenca del Río Magro, prov. de Valencia, España). Coloquios de Paleontología 1, 579-594.

SinITSA, M.V. 2018. Phylogenetic position of Sinotamias and the early evolution of Marmotini (Rodentia, Sciuridae, Xerinae). Journal of Vertebrate Paleontology 38, e1419251. DOI 10.1080/02724634.2017.1419251

Stehlin, H.G. \& Schaub, S. 1951. Die Trigonodontie der simpli- cidentaten Nager. Schweizerische Palaeontologische Abhandlungen 67, 1-385.

Thorington, R.W. \& Santana, E.M. 2007. How to make a flying squirrel: Glaucomys anatomy in phylogenetic perspective. Journal of Mammalogy 88, 882-896.

DOI 10.1644/06-MAMM-S-325R2.1

Thorington, R.W., Schennum, C.E., Pappas, L.A. \& Pitassy, D. 2005. The difficulties of identifying flying squirrels (Sciuridae: Pteromyini) in the fossil record. Journal of Vertebrate Paleontology 25, 950-961. DOI 10.1671/0272-4634(2005)025[0950:TDOIFS]2.0.CO;2

Van Dam, J.A. \& WeltJe, G.J. 1999. Reconstruction of the Late Miocene climate of Spain using rodent palaeocommunity successions: an application of endmember modelling. Palaeogeography, Palaeoclimatology, Palaeoecology 151, 267-305. DOI 10.1016/S0031-0182(99)00015-2

Van der Meulen, A.J., García-Paredes, I., Álvarez-Sierra, M.Á., Van den Hoek Ostende, L.W., Kordisk, K., Oliver, A. \& Peláez-Campomanes, P. 2012. Updated Aragonian biostratigraphy: Small mammal distribution and its implications for the Miocene European chronology. Geologica acta 10, 159-179.

Vasileiadou, K. \& Koufos, G.D. 2005. The micromammals from the Early/Middle Miocene locality of Antonios, Chalkidiki, Greece. Annales de Paléontologie 91, 197-225. DOI 10.1016/j.annpal.2005.06.002

Zheng, S. \& Li, Y. 1982. Some Pliocene lagomorphs and rodents from Loc. 1 of Songshan, Tianzu-Xian, Gansu Province. Vertebrata PalAsiatica 20, 135-144.

ZiegleR, R. \& FAhlbusch, V. 1986. Kleinsäuger-Faunen aus der basalen Oberen Süßwasser-Molasse Niederbayerns. Abhandlungen der Bayerischen Staatssammlung für Paläontologie und historische Geologie, Zitteliana 14, 3-80. 